\title{
36. ORGANIC GEOCHEMISTRY OF SEDIMENTS FROM DEEP SEA DRILLING PROJECT LEG 87, SITES 582 AND 583, NANKAI TROUGH, AND SITE 584, JAPAN TRENCH ${ }^{1}$
}

\author{
Kaichi Sekiguchi and Akio Hirai, Teikoku Oil Co., Ltd., Tokyo ${ }^{2}$
}

\begin{abstract}
Geochemical analyses of organic matter were carried out on Quaternary sediments from Sites 582 and 583 (Nankai Trough) and on Pliocene to Miocene sediments from Site 584 (Japan Trench), DSDP Leg 87, to evaluate petroleum-generating potential and to characterize the organic matter.

The vitrinite-huminite reflectances of indigenous materials for these sites are less than $0.3 \%$ indicating the immature nature of the sediments. The sediments, however, contain remarkable amounts of recycled organic materials. The Quaternary sediments from Sites 582 and 583 contain small amounts of amorphous organic matter (less than 0.75 wt. $\%$ organic carbon and $66-90 \%$ amorphous debris), which is composed of predominantly recycled, oxidized, and over-matured (or matured) Type III material. The amount of hydrocarbon yield indicates that those sediments have lean-source potential for commercial hydrocarbon generation. The Pliocene to Miocene sediments from Site 584 contain organic matter (0.3-1.09 wt. \% organic carbon) of predominantly amorphous debris $(68-96 \%)$ that originated in two sources, an indigenous Type II material and a recycled, over-matured material. Pyrolysis shows an upward increase in the section of hydrocarbon yield and the same trend is also observed in organic-carbon content. The amount of the yield indicates that the Miocene sediments have lean-to-fair source potential and the Pliocene sediments have fair-to-good source potential.
\end{abstract}

\section{INTRODUCTION}

The objectives of this study are to evaluate the petroleum-generating potential of Leg 87 sediments and to characterize the composition of the organic matter preserved in the sediments. Sites 582 and 583 were drilled in the Nankai Trough area and Site 584 near the Japan Trench (Fig. 1). Site 582 is located on the floor of the Nankai Trough, and the trench-fill deposits are dark olive gray to gray turbidites and hemipelagic clays and silts (site chapter, Site 582 , this volume). Site 583 is located on the lowest structural terrace of the landward slope of the trough, and the sediments are dark gray to dark olive gray hemipelagic muds with generally thin and graded sand and silt layers (site chapter, Site 583, this volume). Site 584 is situated on the terrace of the landward trench slope, and the deposits are mainly composed of diatomaceous muds and mudstones (site chapter, Site 584 , this volume).

For this study, we employed the techniques that we normally use to evaluate petroleum source-rock potential. From the whole-sediment analyses, we obtained (1) the contents of organic carbon and carbonate carbon present in a sample, and (2) the hydrocarbon-generating potential of the sample and the nature of organic matter included in the sample using a Rock-Eval apparatus. The vitrinite reflectance and the fractional composition of visual kerogen were obtained from the optical studies of the isolated kerogen concentrate, and elemental analyses of the kerogen concentrate were also performed to check the kerogen types obtained from both the optical examination and the Rock-Eval pyrolysis. Although these

\footnotetext{
${ }^{1}$ Kagami, H., Karig, D. E., Coulbourn, W. T., et al., Init, Repts. DSDP, 87: WashKagami, H., Karig, D. E., Coul
ington (U.S. Govt. Printing Office).

Address: Technical Research Center, Teikoku Oil Co., Ltd., 23-30, Kitakarasuyama 9-Chome, Setagaya-Ku, Tokyo, 157, Japan.
}

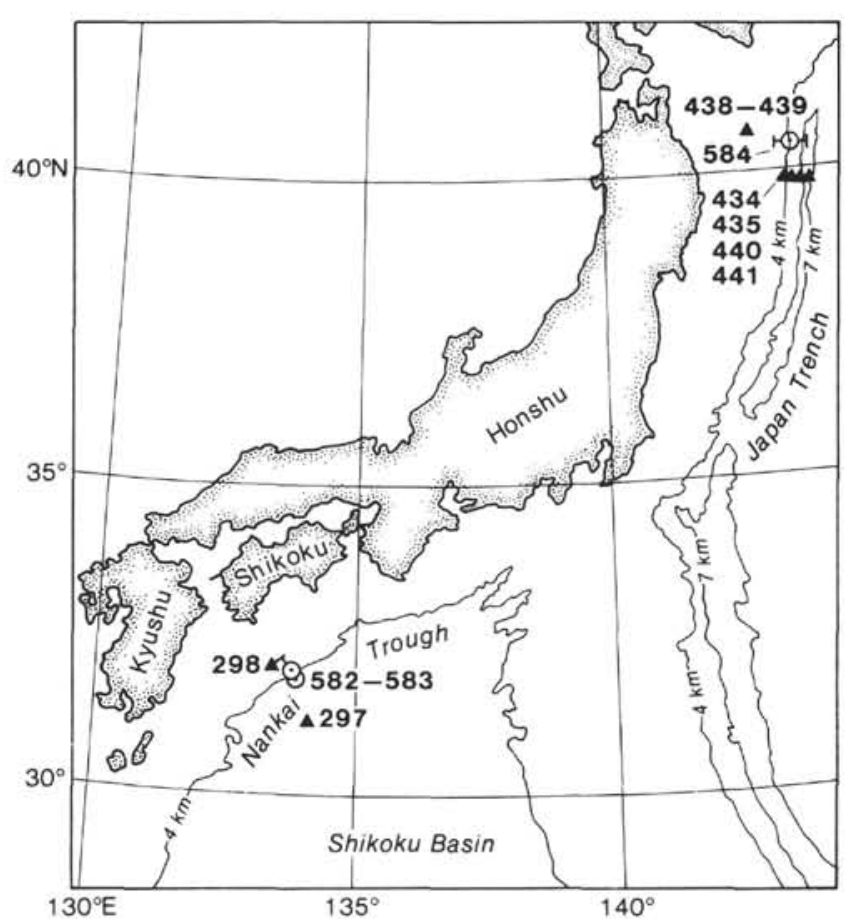

Figure 1. Location of Sites 582, 583, and 584, Leg 87, and of previous DSDP sites in the area.

studies are sufficient to characterize the organic matter at these sites, complete analyses could not be performed because of limitations of sample volume.

\section{EXPERIMENTAL PROCEDURES}

Our laboratory received 224 frozen samples from Leg 87 cores that had been collected in plastic tubes $2.4 \mathrm{~cm}$ in diameter. 


\section{Whole-Sediment Analyses}

The selected samples were dried at $70^{\circ} \mathrm{C}$ for $10 \mathrm{hr}$. and then homogenized and passed through a 200-mesh sieve. The amount of organic carbon $\left(\mathrm{C}_{\text {org }}\right)$ was calculated by subtracting the measured carbonate-carbon content from the measured total carbon content of the wholesediment sample. The total carbon was measured using a Perkin-Elmer Model 240 elemental analyzer. The carbonate carbon $\left(\mathrm{C}_{\mathrm{carb}}\right)$ was determined gravimetrically by acidification of the powdered sample in order to dissolve the carbonate.

Rock-Eval pyrolysis was performed according to the method first described by Espitalié and others (1977). The 100 -mg powdered samples were heated from 250 to $550^{\circ} \mathrm{C}$ (up to $590^{\circ} \mathrm{C}$ in some cases) at a programmed rate of $25^{\circ} \mathrm{C} /$ minute in a helium atmosphere. Free hydrocarbons present in the sample are first released at a temperature lower than $300^{\circ} \mathrm{C}$ and detected by a flameionization detector (FID). This first peak is called $\mathrm{S}_{1}$ (mg HC/g sample). The second peak, $\mathrm{S}_{2}$ (mg HC/g sample), records hydrocarbons produced by pyrolysis of kerogen between 300 and $550^{\circ} \mathrm{C}$ (or $590^{\circ} \mathrm{C}$ ). All analyzed samples recorded a complex pattern of the $S_{2}$ pyrogram as described below. The organic-origin $\mathrm{CO}_{2}$ is generated during the pyrolysis at temperatures up to $390^{\circ} \mathrm{C}$ and detected as the third peak, $\mathrm{S}_{3}$ (mg $\mathrm{CO}_{2} / \mathrm{g}$ sample), by use of a thermal conductivity detector (TCD). The total content of hydrocarbons $\left(S_{1}+S_{2}\right)$ represents the total petroleum-generating potential of the sample, whereas $\mathrm{S}_{2}$ indicates the residual potential that still exists in the sample during subsequent maturation. The ratios of $\mathrm{S}_{2} /$ $\mathrm{C}_{\text {org }}$ and $\mathrm{S}_{3} / \mathrm{C}_{\text {org }}$ are usually called the "hydrogen index" (HI, mg HC/g C $\mathrm{org}_{\mathrm{g}}$ ) and the "oxygen index" (OI, $\mathrm{mg} \mathrm{CO} / \mathrm{g} \mathrm{C}_{\text {org }}$ ), respectively. These variables correlate with the $\mathrm{H} / \mathrm{C}$ and $\mathrm{O} / \mathrm{C}$ ratios, as previously demonstrated by Espitalié and others (1977). The pyrolysis temperature $\left(\mathrm{T}_{\mathrm{m}},{ }^{\circ} \mathrm{C}\right)$ at the maximum generation of the $\mathrm{S}_{2}$ hydrocarbons represents the maturation state of the organic matter present, and the $T_{m}$ correlates with the vitrinite-reflectance $\mathrm{R}_{\mathrm{o}}$ (Vandenbroucke and others, 1983).

\section{Kerogen Analyses}

Kerogen concentrate for microscopic investigation and elemental analysis was obtained from the 5-g ground sample (under 60 -mesh size) by partial demineralization. We used $6 \mathrm{~N}$ hydrochloric acid to remove carbonates, and a subsequent treatment with $56 \%$ hydrofluoric acid (HF) removed most of the silicates. HF treatment was carried out in a water bath adjusted to $95^{\circ} \mathrm{C}$ for 2 hours. Kerogen concentrate was floated off, using a $\mathrm{ZnBr}_{2}$ solution of $2.0 \mathrm{~g} / \mathrm{cm}^{3}$ density. Our preliminary studies did not involve extraction of either humic substances or hydrocarbons, because our main objectives were to determine vitrinite reflectance and to obtain visual kerogen composition. Thus, the isolated kerogen residue may have contained some humic substances and hydrocarbons.

Where a sufficient amount of kerogen concentrate was obtained, we measured the vitrinite-huminite reflectance. Kerogen particles larger than $147 \mu \mathrm{m}$ in diameter were embedded in a plastic mount. After grinding and polishing, a maximum value of reflectance $\left(R_{0}\right)$ was measured by rotating an objective particle (collinite) under a microscope photometer equipped with a Leitz Orthoplan POL in monochromatic (546 nm) light and oil immersion. The Tertiary-Quaternary sequences in Japan usually contain degradinite (Fujii et al., 1979) which is an aggregate of fine particles of vitrinite and liptinite. Degradinite (Stach et al., 1975) closely resembles collinite in appearance under a microscope; so, when the particles are fine, it is difficult to distinguish the collinite component from an aggregate of collinite and degradinite. The reflectance of degradinite is always lower than that of collinite at low thermal levels, less than $1 \% R_{0}$. This phenomenon yields an error in determining thermal maturity of organic matter. Therefore, we usually use large kerogen particles for the measurement of vitrinite reflectance. The measurements were displayed as a histogram with the number of counts per $0.02 \% R_{o}$ interval. An arithmetic mean and standard deviation were calculated for each discrete population in the histogram. The mean value for the lowest vitrinite-huminite reflectance population in each sample was considered to be an indicator of thermal maturity level of an indigenous organic matter.

From observation of the kerogen concentrate in transmitted light using an Olympus BHB microscope, a semiquantitative estimate of the "type of kerogen" was made using designations such as amorphous (AM), herbaceous (HB), and woody-coaly (WC) types based on the categories described by Staplin (1969), Burgess (1974), and McIver (1974). The "amorphous" group comprises fluffy or lumpy sapropelic material, algae, and fine organic material smaller than $5 \mu \mathrm{m}$ in diameter. This fine material, however, may include some humic kerogen except opaque coaly material. The "herbaceous" group comprises nonopaque, recognizable plant material such as spores, pollen, cuticles, and resin. The "woody-coaly" group includes less opaque to opaque plant material of woody origin and opaque coaly material.

After drying at $100^{\circ} \mathrm{C}$ for about 30 minutes, the kerogen concentrate was analyzed for carbon, hydrogen, and nitrogen with a Perkin-Elmer Model 240 elemental analyzer.

\section{RESULTS AND DISCUSSION}

Details of data are reported in Appendixes A, B, and C. The organic-carbon content $\left(\mathrm{C}_{\text {org }}\right)$ and the hydrocarbon yield of the whole sediments $\left(\mathrm{S}_{1}+\mathrm{S}_{2}\right.$, called "genetic potential") and the visual kerogen composition are plotted in Figure 2 as a function of depth. The typical pyrograms by Rock-Eval assays and the hydrogen index (HI) versus oxygen index (OI) are shown respectively in Figures 3 and 4 . The vitrinite-reflectance histogram and the vertical distribution of the mean reflectance (on a log scale) against depth (on a linear scale) are shown respectively in Figures 5 and 6.

\section{Nankai Trough (Sites 582 and 583)}

\section{Organic Carbon and Carbonate Carbon}

The Quaternary sediments from Sites 582 and 583 have organic-carbon contents ranging from 0.35 to $0.75 \%$ in 
weight (Fig. 2, Appendix A). The samples above $500 \mathrm{~m}$ sub-bottom at Site 582 and all samples from Site 583 have more than $0.5 \mathrm{wt} . \%$ organic carbon; this value corresponds to the minimum level of organic carbon for a clastic source-rock of petroleum (Tissot and Welte, 1978). However, in our experience, $1 \mathrm{wt} . \%$ or more organic carbon is needed to consider a sediment as a potential sourcerock of petroleum. The samples below $500 \mathrm{~m}$ at Site 582 are organic-poor sediments having less than $0.5 \mathrm{wt} . \%$ organic carbon.

The geochemical studies of the predominantly hemipelagic sediments of the Shikoku Basin (Sites 442, 443, and 444, Leg 58) by Rullkötter and others (1980) and by
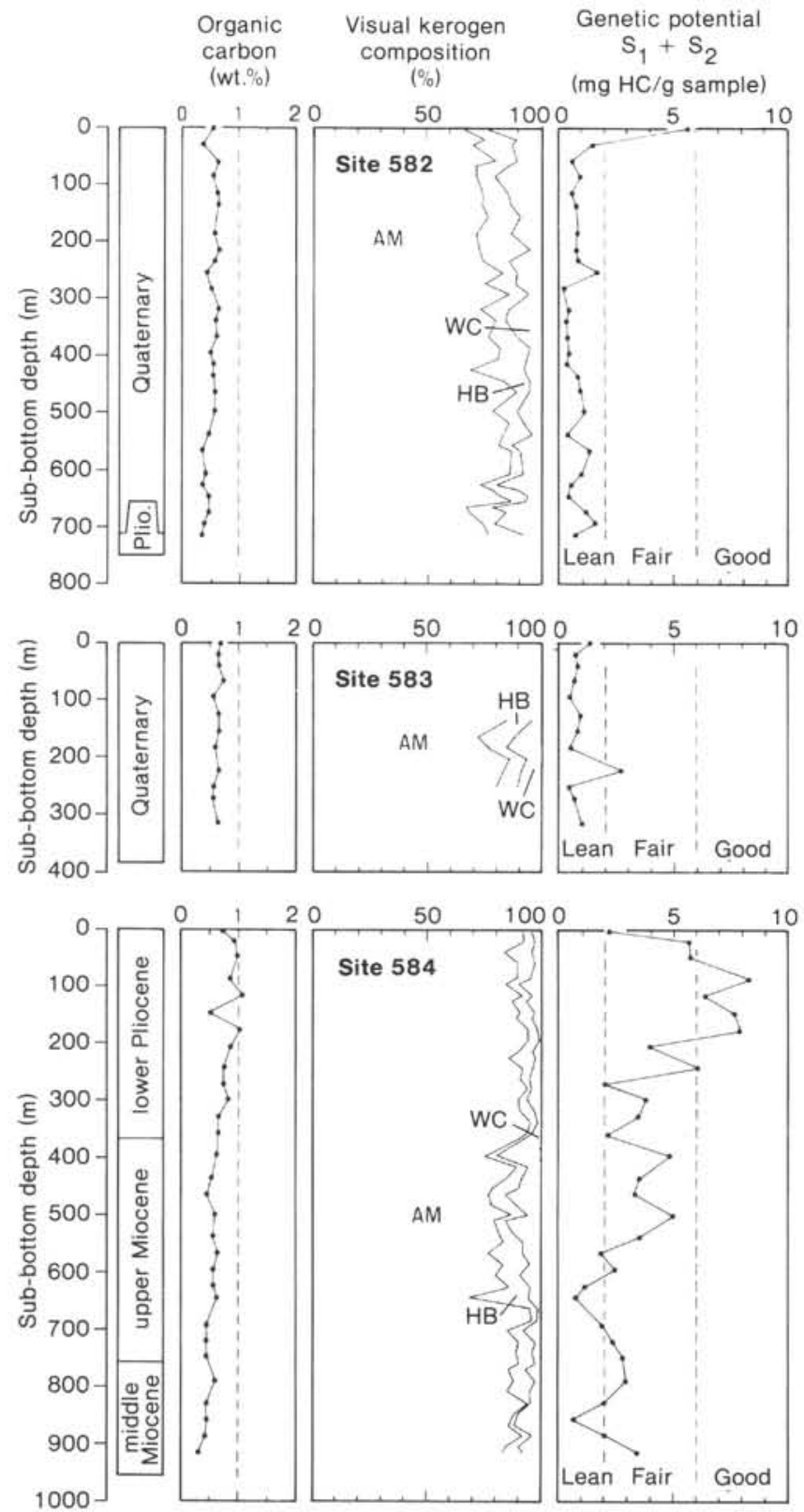

Figure 2. Vertical distribution of organic carbon, visual kerogen, and genetic potential in the sediments, Sites 582, 583, and 584. AM, $\mathrm{HB}$, and WC represent amorphous, herbaceous, and woody-coaly kerogens, respectively.
Waples and Sloan (1980) show that the organic-carbon values range from less than $0.1 \mathrm{wt} . \%$ in the Miocene sediments to around $0.4 \mathrm{wt} . \%$ in the Pleistocene and Holocene sediments. The organic matter in the Quaternary samples from Sites 582 and 583 was probably deposited in a sedimentary environment similar to the Quaternary sediments of the Shikoku Basin, because the values of the organic-carbon contents (about 0.4 to $0.6 \mathrm{wt} . \%$ ) of our samples seem to agree with the abovementioned trend of increasing organic-carbon values from the Miocene to the Holocene.

Most of the sediments from Sites 582 and 583 have a low carbonate-carbon content, ranging from 0.03 to 0.34 wt.\% (Appendix A). Only one sample (583D-3-1) contains more than 1 wt. $\%$ carbonate carbon.

\section{Kerogen Type}

The visual kerogen examinations of the samples from Sites 582 and 583 indicate kerogens dominated by amorphous debris (AM) ranging from 66 to $90 \%$ ( $79 \%$ on the average) as shown in Figure 2 and Appendix B. RockEval assays indicate, however, that this is not sapropelic kerogen of marine origin.

The pyrograms produced by Rock-Eval assays of the whole-sediment samples are generally composed of three $\mathrm{S}_{2}$ peaks (e.g., Samples 582A-15-3 and 582A-22-2, Fig. 3 ). Remarkably low amounts of hydrocarbons were generated from kerogens by pyrolysis at lower temperatures (up to $400^{\circ} \mathrm{C}$ ), and because of the low $\mathrm{T}_{\mathrm{m}}$ values (around $400^{\circ} \mathrm{C}$ ), they are interpreted to be generated from indigenous kerogens. On the other hand, the peaks at higher temperatures, both around $450^{\circ} \mathrm{C}$ and especially above $550^{\circ} \mathrm{C}$, are relatively large and are interpreted to result from recycled, matured, and/or over-matured kerogens.

The $\mathrm{S}_{2}$ pyrogram of Sample 582A-22-2 is composed of three peaks $\left[S_{2}(I), S_{2}\left(R_{1}\right)\right.$, and $\left.S_{2}\left(R_{2}\right)\right]$ shown with dotted lines in Figure 3, because the characteristic pattern of the pyrogram does not come from base-line shift. We corrected this problem as follows. The sample was first heated from 250 to $480^{\circ} \mathrm{C}$ at a programmed rate of $25^{\circ} \mathrm{C} /$ minute, and then the heated sample was cooled to room temperature. After cleaning of the crucible, the column, and the FID detector of the apparatus by blank tests, the sample (preheated up to $480^{\circ} \mathrm{C}$ ) was reheated from 250 to $590^{\circ} \mathrm{C}$. There was no response between 250 and about $480^{\circ} \mathrm{C}$, although a peak corresponding to the $\mathrm{S}_{2}\left(\mathrm{R}_{2}\right)$ in Figure 3 was counted up to $590^{\circ} \mathrm{C}$. The characteristic $S_{2}$ pyrogram [small $S_{2}(I)$ and large $S_{2}\left(R_{1}\right)$ and $\mathrm{S}_{2}\left(\mathrm{R}_{2}\right)$ ] indicates that most of the kerogens are composed mainly of reworked materials.

Although $\mathrm{HI}$ and OI values are meaningful to a single kerogen in chemical composition, it is impossible to measure these values for each $S_{2}$ peak because we can not obtain an organic-carbon content that corresponds to each $\mathrm{S}_{2}$ peak. We have, therefore, obtained only an integrated value including all $\mathrm{S}_{2}$ peaks as the $\mathrm{HI}$ variable of the sample, counting only the hydrocarbons generated up to $590^{\circ} \mathrm{C}$ because that is the maximum programmed temperature of our apparatus. As shown in the HI-versus-OI diagram (Fig. 4), the kerogens indi- 

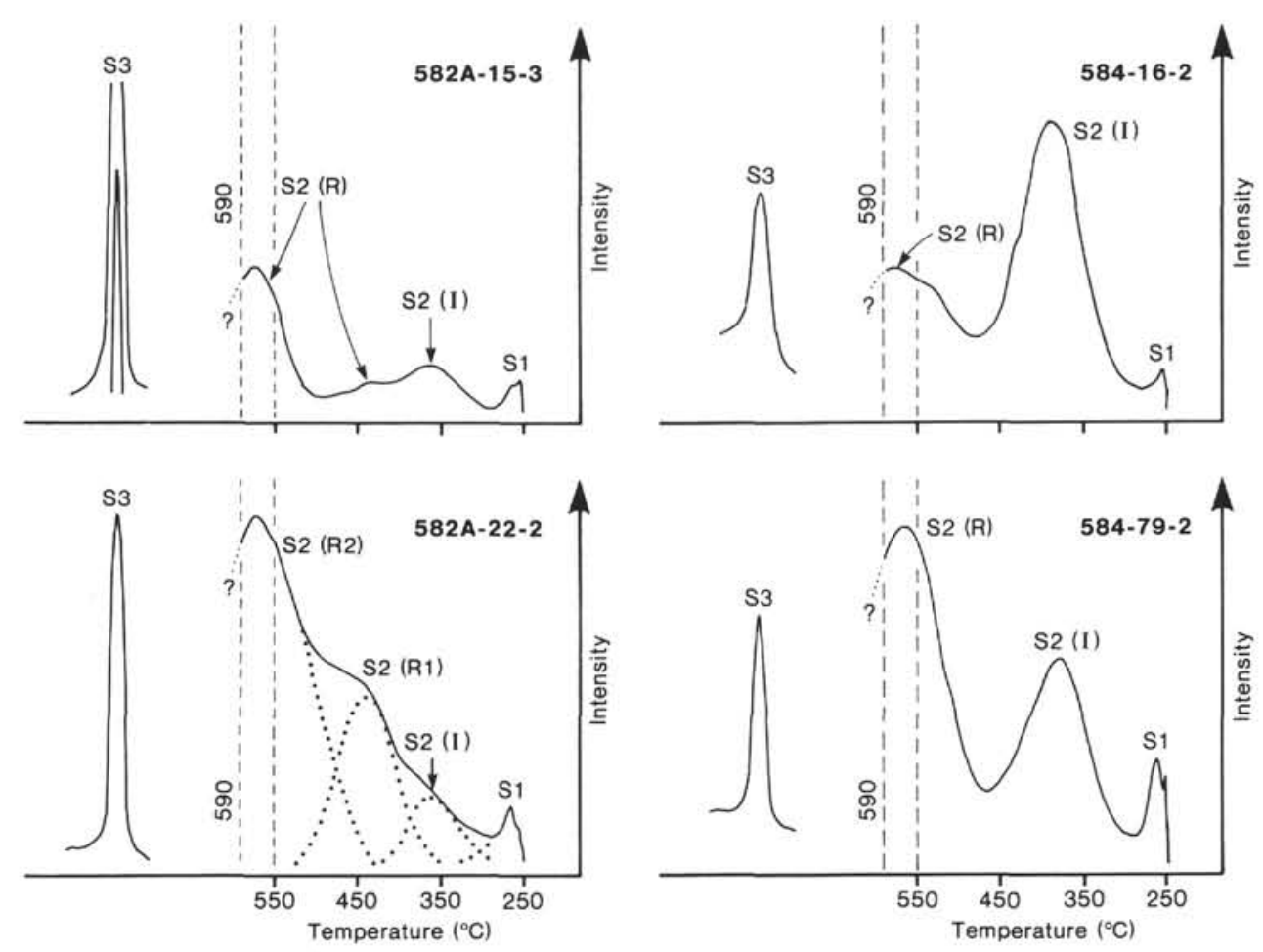

Figure 3. Typical pyrograms. (I) and (R) show indigenous and recycled $\mathrm{S}_{2}$ peaks, respectively.

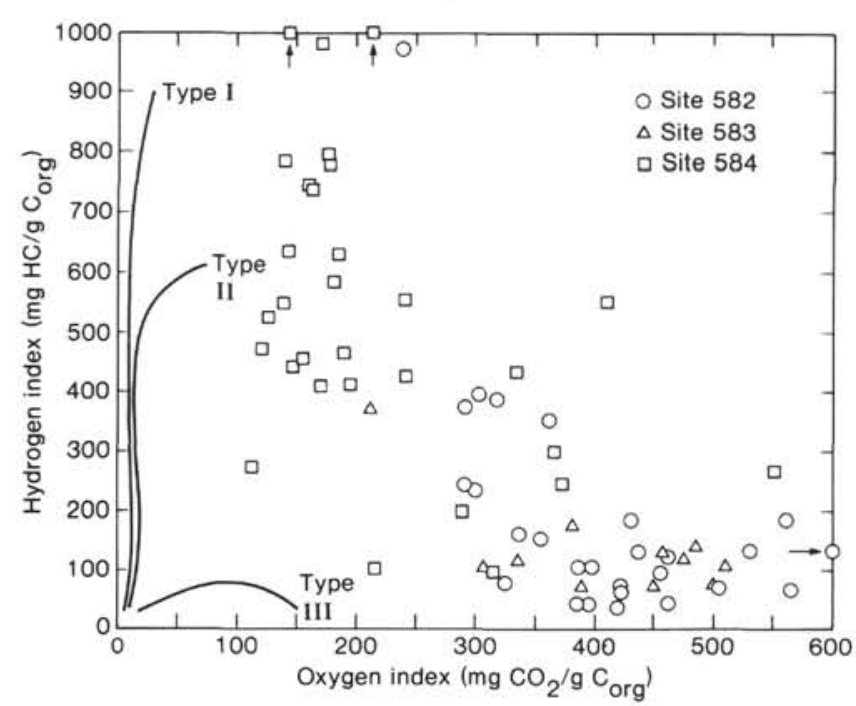

Figure 4. Hydrogen index versus oxygen index for Sites 582, 583, and 584.

cated by circles (Site 582) and triangles (Site 583) are mainly Type III (Tissot et al., 1974). The high OI values imply that most of the kerogens were oxidized during both erosion of their mother rocks and their redeposition.

In summary, the kerogens in the Quaternary sediments from Sites 582 and 583 are composed mainly of amorphous debris of terrigenous origin (Type III), and nearly all the kerogens have been derived from matured and/or over-matured older rocks. Similarly, Quaternary sedi- ments of the Shikoku Basin contain a large amount of recycled organic matter (Rullkötter et al., 1980).

\section{Thermal Maturity}

Thermal maturity of the sediments from Sites 582 and 583 was estimated from the mean value of maximum vitrinite-huminite reflectance, and the temperature at the maximum generation of $\mathrm{S}_{2}$ hydrocarbons was not applied because of its complex pyrolysis curve, as mentioned above.

Although some of the samples analyzed had more than one population of reflectance (Fig. 5, Appendix C), only the lowest population was believed to be the primary one, indicating the thermal maturity of the indigenous organic matter. The higher populations probably represent recycled materials derived from older rocks.

As shown in Figure 6, a combined depth distribution of reflectance values of Sites 582 and 583 is a maturation profile of indigenous kerogens present in those sites. This profile indicates that the sediments drilled at Sites 582 and 583 are immature. In the interval from the sea bottom to about $300 \mathrm{~m}$ sub-bottom, the indigenous-vitrinite reflectances are around $0.2 \%$, and the reflectances increase with depth below $300 \mathrm{~m}$. Because drilling at Site 582 penetrated no more than $700 \mathrm{~m}$ of sediment, it was very difficult to determine the true maturation trend of indigenous organic materials. If the three points circled with dots in Figure 6 are representative of recycled particles, the dashed line in the figure probably represents the in situ maturation trend. This trend implies that the underlying sediments may reach values of $0.5 \%$ 


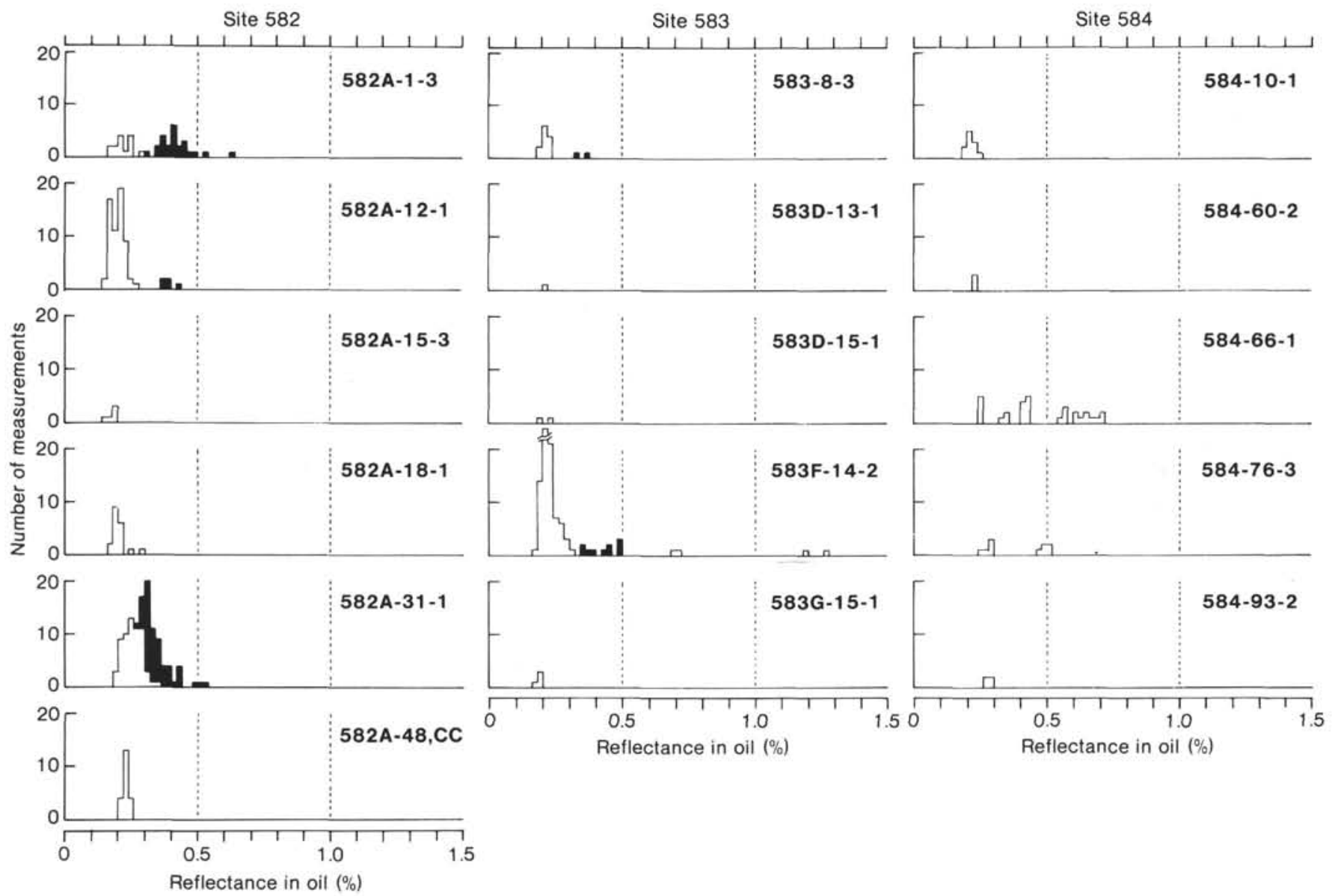

Figure 5. Reflectance histograms of vitrinite-huminite and inertinite, Sites 582, 583, and 584. White and black indicate vitrinite-huminite and inertinite, respectively.

$R_{o}$ (petroleum-generating threshold) at about $1600 \mathrm{~m}$ subbottom.

\section{Hydrocarbon Potential}

Data concerning the quantity, quality, and maturity of the organic matter indicate that the Quaternary sediments drilled at Sites 582 and 583 have no source potential for commercial hydrocarbon generation. This conclusion is based on low hydrocarbon yields $\left(S_{1}+S_{2}\right.$, genetic potential), less than $2 \mathrm{mg} \mathrm{HC} / \mathrm{g}$ sample (Fig. 2). Recycled organic material would generate a small amount of gas if subjected to higher-temperature metamorphism than it has experienced to date.

\section{Japan Trench (Site 584)}

\section{Organic Carbon and Carbonate Carbon}

Measured organic-carbon contents of sediments from Site 584 range between 0.30 and 1.09 wt. $\%$; the highest value was found in a Pliocene sample (584-13-4) and the lowest one in a middle Miocene sample (584-96-1) (Appendix A). The Miocene sediments, with about 0.5 wt. $\%$ organic carbon on the average, are ranked among the poor sources for commercial hydrocarbon generation; on the other hand, the analyzed Pliocene sediments have organic carbon ranging from 0.64 to $1.09 \mathrm{wt} . \%$; these are fair-to-good potential source rocks of petroleum. The organic-carbon values gradually increase from about $0.5 \mathrm{wt} . \%$ in the uppermost Miocene sediments to about $1 \mathrm{wt} . \%$ in the middle part of the lower Pliocene.

All samples from Site 584 have low carbonate-carbon content, with values ranging from 0.01 to $0.46 \mathrm{wt} . \%$ (Appendix A). These values are considerably less than those of the Nankai Trough area (Sites 582 and 583).

\section{Kerogen Type}

The visual-kerogen analyses of the samples from Site 584 indicate that kerogens are mainly composed of amorphous debris (AM), ranging from 68 to $96 \%$, with an average of $87 \%$ (Fig. 2, Appendix B).

The $S_{2}$ pyrograms of all the whole-sediment samples analyzed are represented by a bimodal pattern including $\mathrm{S}_{2}(\mathrm{I})$ and $\mathrm{S}_{2}(\mathrm{R})$ peaks (Fig. 3 ). $\mathrm{S}_{2}(\mathrm{I})$ occurs at low temperatures around $400^{\circ} \mathrm{C}$ (Appendix A) and probably results from thermal cracking of indigenous kerogens because of its low $T_{m}$ value. $S_{2}(R)$ has its peak temperature above $550^{\circ} \mathrm{C}$ and is considered to be generated by thermal cracking of recycled, over-matured kerogens. According to the predicted path of kerogen evolution (Tissot et al., 1974), it is surprising for such recycled, over-matured materials to generate amounts of hydrocarbons as large as those shown in Sample 584-79-2 (Fig. 3). Although such a large $S_{2}(R)$ peak leads to a high $H I$ value, 

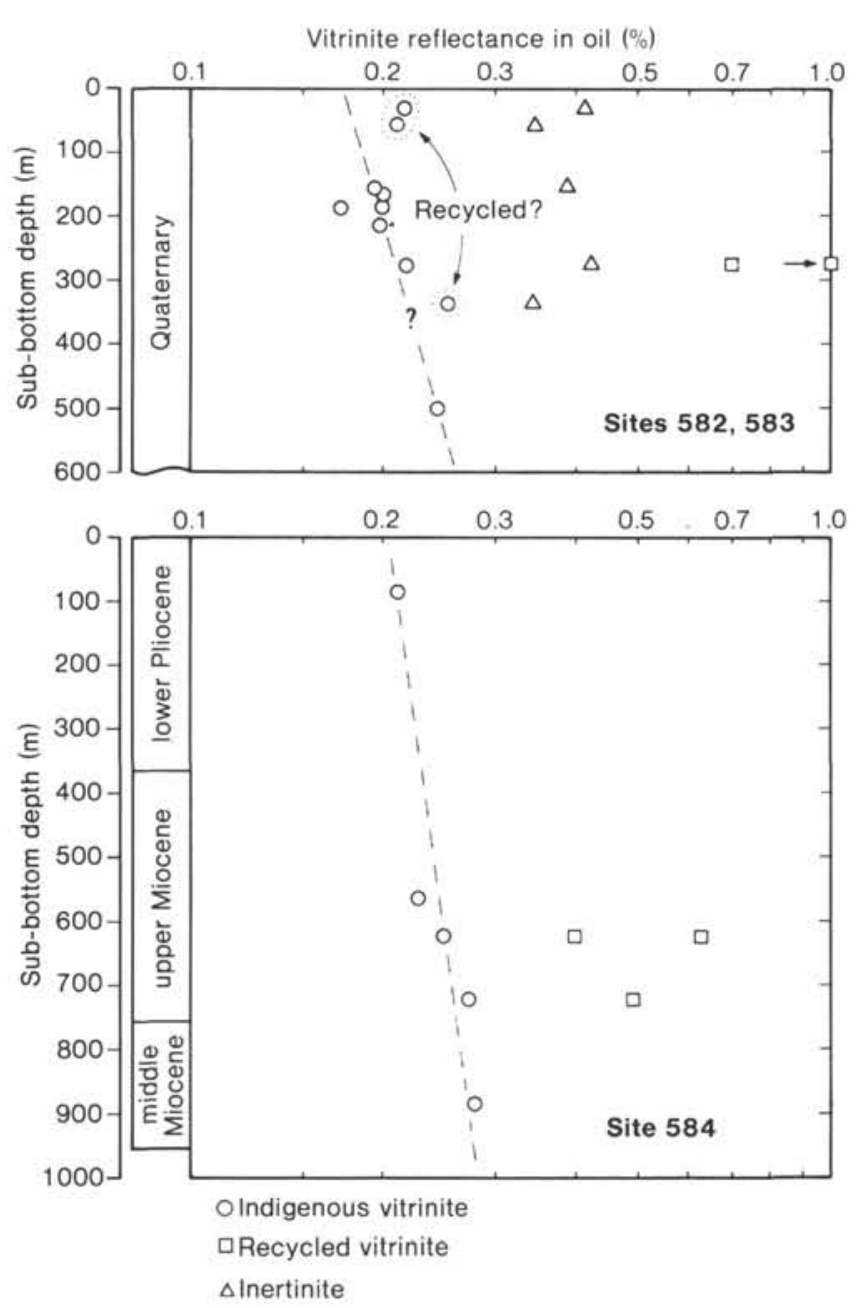

Figure 6. Mean reflectance as a function of sub-bottom depth for Sites 582,583 , and 584 .

we could not determine the nature of the materials exactly.

Using the same methods as mentioned for the Nankai Trough, we obtained an integrated HI value composed of hydrocarbons generated from both indigenous and recycled kerogens; therefore, the kerogen typing using the $\mathrm{HI}$ and $\mathrm{OI}$ values gave false information on the type of kerogens present in the samples from Site 584. The values calculated, however, show remarkable differences between the results from the Nankai Trough and those from the Japan Trench. Specifically, most of the samples collected from Site 584 have higher HI values and lower OI values than those from the Nankai Trough area, Sites 582 and 583 (Fig. 4).

Samples having high $\mathrm{HI}$ values ( $\geq 400 \mathrm{mg} \mathrm{HC} / \mathrm{g} \mathrm{C}_{\text {org }}$ ) and low OI values ( $\leq 250 \mathrm{mg} \mathrm{CO} / \mathrm{g} \mathrm{C}_{\text {org }}$ ) are interpreted to be predominately immature Type II kerogens with some recycled, over-matured kerogens. The lower HI values ( 400 to 200 ) can probably be explained by dilution of such immature pyrolyzable kerogens with recycled, low-hydrogen and high-oxygen kerogens. Samples having the lowest HI values $(\leq 200)$ have no distinct $\mathrm{S}_{2}$ (I) peak at low temperatures around $400^{\circ} \mathrm{C}$ and mainly show the nature of recycled materials with peak temperatures above $550^{\circ} \mathrm{C}$.
Therefore, most of the sediments from Site 584 contain immature Type II kerogens that are accompanied by recycled kerogens, and others contain mainly recycled kerogens.

\section{Thermal Maturity}

On the basis of the lowest population of vitrinite reflectance (Appendix C, Figs. 5 and 6), the thermal maturity of sediments from Site 584 is very low, below $0.3 \%$ $R_{0}$. This result is supported by the low $T_{m}$ values around $400^{\circ} \mathrm{C}$ of indigenous kerogens (Appendix A).

\section{Hydrocarbon Potential}

The total hydrocarbon yields $\left(\mathrm{S}_{1}+\mathrm{S}_{2}\right)$ obtained from the Site 584 samples vary markedly throughout the analyzed section (Fig. 2). The deepest section, from about 921 to $560 \mathrm{~m}$ sub-bottom (the middle Miocene to the middle part of the upper Miocene), yields $0.24-3.47 \mathrm{mg}$ $\mathrm{HC} / \mathrm{g}$ sample (2.02 on the average), the lowest among the whole section analyzed. The intermediate section, from about 540 to $270 \mathrm{~m}$ (the middle part of the upper Miocene to the lower part of the lower Pliocene), yields $1.96-4.89 \mathrm{mg} \mathrm{HC} / \mathrm{g}$ sample (3.49 on the average); these values correspond to fair source potential for commercial hydrocarbon generation. The shallowest section, above $240 \mathrm{~m}$ (the middle to upper part of the lower Pliocene), has high values of $2.18-8.32 \mathrm{mg} \mathrm{HC} / \mathrm{g}$ sample (5.95 on the average); these values correspond to fair-togood source potential. Vertical distribution of hydrocarbon yields, as mentioned above, is roughly comparable to that of organic-carbon contents (Fig. 2).

\section{CONCLUSION}

The organic material in the Quaternary sediments from Sites 582 and 583 in the Nankai Trough is predominately of amorphous type, of terrigenous origin (Type III), and oxidized and over-matured (or matured). This material probably originated from a recycled source from an adjacent land area. The maturity level of the sediments, however, is very low, an assessment based on the reflectance of substantially indigenous materials. The sediments have no source potential for commercial hydrocarbon generation.

The organic material from the Miocene to the Pliocene at Site 584 near the Japan Trench originated from two sources, an indigenous Type II material and a recycled, over-matured material. The latter was probably derived from an adjacent land area. Both reflectance and pyrolysis indicate that the sediments are immature. Pyrolysis shows progressive upward increases in hydrocarbon yield throughout the whole section, and the same trend is also observed in organic-carbon content. The Miocene sediments have lean-to-fair source potential and the Pliocene sediments have fair-to-good source potential for commercial hydrocarbon generation.

\section{ACKNOWLEDGMENTS}

The authors thank Drs. H. Kagami and D. E. Karig, Leg 87 CoChief Scientists, for entrusting them with this study. The authors also thank the Teikoku Oil Company for permission to participate in this work and are very grateful to Dr. Y. Ishiwada (Director of Arctic Petroleum Cooperation of Japan) and Dr. N. Komatsu (Director of Teikoku Oil Co.) for the opportunity to contribute to this volume. The 
authors also thank Dr. Y. Fujita (Director of Technical Research Center) and Mr. A. Tomizawa for their valuable suggestions and for critically reading the manuscript. Thanks are due to Mr. Y. Miyamoto and Miss K. Fujimoto for Rock-Eval and elemental analyses. The authors also thank Miss C. Furuyama and Miss F. Kanaizumi for extensive typing and drafting of figures.

\section{REFERENCES}

Burgess, J. D., 1974. Microscopic examination of kerogen (dispersed organic matter) in petroleum exploration. Geol. Soc. Am., Spec. Publ., 153:19-30.

Espitalié, J., Laporte, J. L., Madec, M., Marquis, F., Leplat, P., Paulet, J., and Boutefeu, A., 1977. Métode rapide de caractérisation des roches mères, de leur potentiel pétrolier et de leur degré d'évolution. Rev. Inst. Fr. Pet., 32:23-42.

Fujii, K., Yonetani, H., Sogabe, M., Sasaki, M., and Higashide, N., 1979. Coal petrological studies of the sub-bituminous coal in the Kushiro coal field, Hokkaido, Japan-as basic data for oil exploration off Kushiro. J. Jpn. Assoc. Pet. Technol., 44:(3):134-143. (in Japanese)

McIver, R. D., 1967. Composition of kerogen-clue to its role in the origin of petroleum. Proc. 7th World Petroleum Congr., 2:25-36.

Rullkötter, J., Flekken, P., and Welte, D. H., 1980. Organic petrography and extractable hydrocarbons of sediments from the northern Philippine Sea, Deep Sea Drilling Project Leg 58. In Klein, G.
deV., Kobayashi, K., et al., Init. Repts. DSDP, 58: Washington (U.S. Govt. Printing Office), 755-761.

Stach, E., Mackowsky, M. T., Teichmüller, M., Taylor, G. H. Chandra, D., and Teichmüller, R., 1975. Coal Petrology: Berlin-Stuttgart (Gebruder Borntrager).

Staplin, F. L., 1969. Sedimentary organic matter, organic metamorphism, and oil and gas occurrence. Can. Pet. Geol. Bull., 17:47-66.

Tissot, B., Durand, B., Espitalié, J., and Combaz, A., 1974. Influence of nature and diagenesis of organic matter in formation of petroleum. Am. Assoc. Pet. Geol. Bull., 58(3):499-506.

Tissot, B. P., and Welte, D. H., 1978. Petroleum Formation and Occurrence: Berlin, Heidelberg, New York (Springer-Verlag).

Vandenbroucke, M., Durand, B., and Oudin, J. L., 1983. Detecting migration phenomena in a geological series by means of $\mathrm{C}_{1}-\mathrm{C}_{35}$ hydrocarbon amounts and distributions. In Bjorøy, M., Albrecht, P., Cornford, C., de Groot, K., Eglinton, G., Leythaeuser, D., Pelet, R., Rullkötter, J., and Speers, G. (Eds.), Advances in Organic Geochemistry 1981: Chichester (John Wiley and Sons), pp. 147-155.

Waples, D. W., and Sloan, J. R., 1980. Carbon and nitrogen profiles in deep-sea sediments: new evidence for bacterial diagenesis at great depths of burial. In Klein, G. deV., Kobayashi, K., et al., Init. Repts. DSDP, 58: Washington (U.S. Govt. Printing Office), 745-754.

Date of Initial Receipt: 4 January 1984

Date of Acceptance: 12 April 1984 
APPENDIX A

Whole-Sediment Analyses: Carbon and Rock-Eval Data

\begin{tabular}{|c|c|c|c|c|c|c|c|c|c|c|c|}
\hline \multirow{3}{*}{$\begin{array}{l}\text { Hole-Core-Section } \\
\text { (interval in } \mathrm{cm} \text { ) }\end{array}$} & \multirow{3}{*}{$\begin{array}{l}\text { Sub-bottom } \\
\text { depth } \\
\text { (m) }\end{array}$} & \multicolumn{2}{|c|}{ Carbon } & \multicolumn{8}{|c|}{ Rock-Eval pyrolysis } \\
\hline & & \multirow{2}{*}{$\begin{array}{l}\text { Corg } \\
\text { (wt.\%) }\end{array}$} & \multirow{2}{*}{$\begin{array}{l}\mathrm{C}_{\mathrm{carb}} \\
\text { (wt.\%) }\end{array}$} & & & & & & & $\operatorname{Tm}\left({ }^{\circ} \mathrm{C}\right)$ & \\
\hline & & & & (mg HC/g S) & $(\mathrm{mg} \mathrm{HC} / \mathrm{g} \mathrm{S})$ & $\left(\mathrm{mg} \mathrm{CO}_{2} / 8 \mathrm{~S}\right)$ & (mg HC/8 Corg) & (mg CO $2 / 8 C_{\text {org }}$ ) & 1 & $\mathrm{R}_{1}$ & $\mathbf{R}_{2}$ \\
\hline Site 582 & & & & & & & & & & & \\
\hline $582-1-4,70-74$ & $0.00-5.22$ & 0.57 & 0.03 & 0.11 & 5.54 & 1.36 & 971 & 239 & & & $>550$ \\
\hline $582 \mathrm{~A}-1-3,130-134$ & $29.10-33.42$ & 0.38 & 0.17 & 0.07 & 1.33 & 1.37 & 350 & 361 & & & $>550$ \\
\hline $582 A-2-3,22-26$ & $58.20-61.44$ & 0.68 & 0.25 & 0.06 & 0.48 & 3.45 & 71 & 504 & & 444 & $>550$ \\
\hline 582A-5-1, 63-66 & $87.30-87.96$ & 0.57 & 0.19 & 0.08 & 0.91 & 1.92 & 160 & 337 & & 451 & $>550$ \\
\hline $582 \mathrm{~A}-8-2,100-105$ & $116.10-118.63$ & 0.65 & 0.22 & 0.09 & 0.52 & 2.11 & 80 & 325 & & 441 & $>550$ \\
\hline $582 \mathrm{~A}-10-5,82-87$ & $135.50-142.35$ & 0.67 & 0.30 & 0.07 & 0.71 & 2.59 & 106 & 387 & & 447 & $>550$ \\
\hline $582 A-15-3,62-67$ & $183.60-187.24$ & 0.58 & 0.19 & 0.06 & 0.77 & 2.54 & 133 & 438 & 369 & & $>550$ \\
\hline $582 \mathrm{~A}-18-1,45-50$ & $212.50-212.97$ & 0.67 & 0.19 & 0.07 & 0.69 & 2.66 & 103 & 397 & & 461 & $>550$ \\
\hline $582 \mathrm{~A}-20-1,89-94$ & $231.90-232.82$ & 0.59 & 0.19 & 0.06 & 0.72 & 2.72 & 126 & 461 & & & $>550$ \\
\hline $582 A-22-2,61-65$ & $251.10-253.23$ & 0.42 & 0.02 & 0.06 & 1.63 & 1.34 & 388 & 319 & & & $>550$ \\
\hline $582 \mathrm{~A}-25-1,60-65$ & $279.90-280.53$ & 0.51 & 0.22 & 0.07 & 0.21 & 2.14 & 41 & 420 & & & $>550$ \\
\hline $582 \mathrm{~A}-29-1,116-120$ & $318.30-319.48$ & 0.65 & 0.34 & 0.05 & 0.42 & 2.74 & 65 & 422 & & 451 & $>550$ \\
\hline $582 A-31-1,138-143$ & $337.50-338.91$ & 0.59 & 0.23 & 0.05 & 0.26 & 2.33 & 44 & 395 & & 467 & $>550$ \\
\hline $582 \mathrm{~A}-34-1,68-73$ & $365.90-366.61$ & 0.60 & 0.33 & 0.06 & 0.29 & 2.77 & 48 & 462 & & 445 & $>550$ \\
\hline $582 A-37-1,41-46$ & $394.30-394.74$ & 0.49 & 0.22 & 0.05 & 0.35 & 2.07 & 71 & 422 & & 454 & $>550$ \\
\hline $582 \mathrm{~A}-39-3,24-29$ & $413.20-416.47$ & 0.55 & 0.29 & 0.05 & 0.25 & 2.12 & 45 & 385 & & 445 & $>550$ \\
\hline $582 \mathrm{~A}-41-2,97-103$ & $432.00-434.50$ & 0.56 & 0.25 & 0.05 & 0.74 & 2.97 & 132 & 530 & & 430 & $>550$ \\
\hline $582 \mathrm{~A}-44-1,70-73$ & $460.50-461.22$ & 0.58 & 0.12 & 0.04 & 0.88 & 2.06 & 152 & 355 & & & $>550$ \\
\hline $582 \mathrm{~A}-48, \mathrm{CC}$ & $498.60-499.76$ & 0.57 & 0.14 & 0.05 & 1.05 & 2.45 & 184 & 430 & & 456 & $>550$ \\
\hline $582 A-52-2,28-30$ & $537.00-538.79$ & 0.47 & 0.20 & 0.04 & 0.46 & 2.15 & 98 & 457 & & 468 & $>550$ \\
\hline $582 A-55-2,63-66$ & $566.00-568.15$ & 0.35 & 0.02 & 0.03 & 1.31 & 1.02 & 374 & 291 & & & $>550$ \\
\hline $582 \mathrm{~A}-59-2,60-62$ & $604.50-606.61$ & 0.40 & 0.10 & 0.03 & 0.93 & 1.20 & 233 & 300 & & 460 & $>550$ \\
\hline 582A-61-1, 47-49 & $623.70-624.18$ & 0.35 & 0.20 & 0.03 & 0.47 & 2.23 & 134 & 637 & & 447 & $>550$ \\
\hline $582 \mathrm{~A}-63-1,84-86$ & $642.90-643.75$ & 0.46 & 0.50 & 0.04 & 0.32 & 2.60 & 70 & 565 & & 442 & $>550$ \\
\hline $582 \mathrm{~A}-66-3,41-43$ & $671.80-675.22$ & 0.46 & 0.09 & 0.04 & 1.11 & 1.34 & 241 & 291 & & & $>550$ \\
\hline $582 \mathrm{~A}-68-1,146-148$ & $691.20-692.67$ & 0.39 & 0.06 & 0.03 & 1.54 & 1.18 & 395 & 303 & & 474 & $>550$ \\
\hline $582 \mathrm{~A}-70-2,48-51$ & $710.60-712.61$ & 0.36 & 0.29 & 0.04 & 0.67 & 2.02 & 186 & 561 & 405 & & $>550$ \\
\hline Site 583 & & & & & & & & & & & \\
\hline $583 \mathrm{~B}-2-3,24-26$ & $5.00-8.25$ & 0.68 & 0.14 & 0.08 & 1.20 & 2.60 & 176 & 382 & & 456 & $>550$ \\
\hline $583 C-5-2,64-66$ & $20.00-22.16$ & 0.61 & 0.10 & 0.08 & 0.63 & 1.87 & 103 & 307 & & & $>550$ \\
\hline $583 C-4-1,44-48$ & $40.00-40.46$ & 0.67 & 0.13 & 0.05 & 0.77 & 2.25 & 115 & 336 & & 447 & $>550$ \\
\hline 583D-3-1, 76-80 & $66.00-67.78$ & 0.74 & 1.10 & 0.08 & 0.55 & 3.70 & 74 & 500 & 415 & & $>550$ \\
\hline 583D-6-2, 64-68 & $95.00-97.16$ & 0.55 & 0.20 & 0.06 & 0.39 & 2.14 & 71 & 389 & & 454 & $>550$ \\
\hline 583D-9-2, 110-114 & $123.70-126.32$ & 0.65 & 0.21 & 0.08 & 0.83 & 2.97 & 128 & 457 & & 442 & $>550$ \\
\hline 583D-12-1, 136-140 & $152.60-153.98$ & 0.66 & 0.26 & 0.06 & 0.71 & 3.36 & 108 & 509 & & 442 & $>550$ \\
\hline 583D-15-1, 40-45 & $181.70-182.13$ & 0.59 & 0.27 & 0.05 & 0.42 & 2.65 & 71 & 449 & & 451 & $>550$ \\
\hline 583D-19-1, 124-128 & $220.20-221.46$ & 0.65 & 0.02 & 0.07 & 2.41 & 1.38 & 371 & 212 & & 450 & $>550$ \\
\hline 583D-22-2, 23-28 & $249.30-251.06$ & 0.55 & 0.21 & 0.06 & 0.39 & 2.76 & 71 & 502 & & 441 & $>550$ \\
\hline 583D-24-4, 90-95 & $268.70-274.13$ & 0.53 & 0.19 & 0.06 & 0.63 & 2.52 & 119 & 475 & & 445 & $>550$ \\
\hline $583 \mathrm{D}-29-2,20-25$ & $316.90-318.63$ & 0.64 & 0.23 & 0.05 & 0.91 & 3.10 & 142 & 484 & & 437 & $>550$ \\
\hline Site 584 & & & & & & & & & & & \\
\hline $584-1-3,118-123$ & $0.00-4.21$ & 0.75 & 0.46 & 0.18 & 2.00 & 4.13 & 267 & 551 & & $425 />550$ & \\
\hline $584-3-2,89-94$ & $20.00-22.42$ & 0.94 & 0.03 & 0.19 & 5.48 & 1.71 & 583 & 182 & & $433 />550$ & \\
\hline $584-6-1,113-118$ & $48.20-49.36$ & 0.99 & 0.12 & 0.24 & 5.47 & 4.06 & 553 & 410 & 419 & $>550$ & \\
\hline $584-10-1,113-118$ & $86.50-87.66$ & 0.83 & 0.01 & 0.19 & 8.13 & 1.42 & 980 & 171 & 390 & $>550$ & \\
\hline $584-13-4,83-85$ & $115.10-120.44$ & 1.09 & 0.08 & 0.24 & 6.03 & 2.62 & 553 & 240 & & $437 />550$ & \\
\hline $584-16-2,113-118$ & $144.00-146.66$ & 0.49 & 0.01 & 0.16 & 7.41 & 0.71 & 1512 & 144 & 400 & $>550$ & \\
\hline $584-19-1,113-118$ & $173.10-174.26$ & 1.03 & 0.01 & 0.25 & 7.65 & 1.66 & 743 & 161 & 394 & $>550$ & \\
\hline $584-22-1,63-64$ & $202.10-202.73$ & 0.86 & 0.07 & 0.17 & 3.72 & 2.87 & 433 & 334 & & $441 />550$ & \\
\hline $584-26-1,74-76$ & $240.30-241.05$ & 0.74 & 0.01 & 0.17 & 5.90 & 1.31 & 797 & 177 & 411 & $>550$ & \\
\hline $584-29-2,114-117$ & $268.80-271.46$ & 0.74 & 0.22 , & 0.15 & 1.81 & 2.76 & 245 & 373 & 403 & $>550$ & \\
\hline $584-32-1,79-81$ & $297.30-298.10$ & 0.82 & 0.02 & 0.18 & 3.63 & 1.21 & 443 & 148 & 420 & $>550$ & \\
\hline $584-35-3,32-36$ & $326.00-329.34$ & 0.64 & 0.01 & 0.15 & 3.36 & 0.81 & 525 & 127 & 395 & $>550$ & \\
\hline $584-38-1,92-94$ & $354.60-355.53$ & 0.67 & 0.23 & 0.14 & 2.00 & 2.45 & 299 & 366 & 394 & $>550$ & \\
\hline $584-42-4,80-82$ & $392.90-398.21$ & 0.61 & 0.01 & 0.15 & 4.74 & 1.08 & 777 & 177 & & $447 />550$ & \\
\hline $584-46-1,62-66$ & $431.50-432.15$ & 0.53 & 0.02 & 0.09 & 3.37 & 0.76 & 636 & 143 & & $435 />550$ & \\
\hline $584-49-2,125-128$ & $460.10-462.87$ & 0.43 & 0.02 & 0.11 & 3.18 & 0.70 & 740 & 163 & & $>550$ & \\
\hline $584-53-1,86-89$ & $498.50-499.38$ & 0.60 & 0.03 & 0.17 & 4.71 & 0.84 & 785 & 140 & & $>550$ & \\
\hline $584-57-3,92-94$ & $536.60-540.53$ & 0.53 & 0.06 & 0.15 & 3.34 & 0.98 & 630 & 185 & & $433 />550$ & \\
\hline $584-60-2,12-15$ & $565.10-566.74$ & 0.65 & 0.02 & 0.07 & 1.76 & 0.73 & 271 & 112 & & $436 />550$ & \\
\hline $584-63-1,64-67$ & $593.60-594.26$ & 0.57 & 0.05 & 0.12 & 2.33 & 0.97 & 409 & 170 & 396 & $>550$ & \\
\hline $584-66-1,7-9$ & $622.40-622.48$ & 0.58 & 0.04 & 0.05 & 1.16 & 1.67 & 200 & 288 & & $495 />550$ & \\
\hline $584-68-1,109-112$ & $641.80-642.90$ & 0.61 & 0.03 & 0.06 & 0.63 & 1.32 & 103 & 216 & & $489 />550$ & \\
\hline $584-73-1,114-116$ & $690.20-691.35$ & 0.44 & 0.01 & 0.09 & 1.81 & 0.86 & 411 & 195 & & $436 />550$ & \\
\hline $584-76-3,40-45$ & $719.10-722.53$ & 0.47 & 0.02 & 0.13 & 2.20 & 0.89 & 468 & 189 & & $460 />550$ & \\
\hline $584-79-2,30-33$ & $748.00-749.82$ & 0.46 & 0.03 & 0.23 & 2.53 & 0.64 & 550 & 139 & 379 & $>550$ & \\
\hline $584-83-2,144-146$ & $786.40-789.35$ & 0.60 & 0.01 & 0.15 & 2.73 & 0.93 & 455 & 155 & 411 & $>550$ & \\
\hline $584-87-1,133-134$ & $825.20-826.54$ & 0.44 & 0.06 & 0.15 & 1.88 & 1.06 & 427 & 241 & & $>550$ & \\
\hline $584-90-1,118-121$ & $854.00-855.20$ & 0.47 & 0.12 & 0.12 & 0.46 & 1.48 & 98 & 315 & 410 & $>550$ & \\
\hline $584-93-2,7-10$ & $883.10-884.69$ & 0.42 & 0.01 & 0.12 & 1.98 & 0.51 & 471 & 121 & 424 & $>550$ & \\
\hline $584-96-1,147-149$ & $911.20-912.68$ & 0.30 & 0.03 & 0.10 & 3.37 & 0.64 & 1123 & 213 & 428 & $>550$ & \\
\hline
\end{tabular}

Note: $\mathrm{C}_{\text {org }}=$ organic carbon; $\mathrm{C}_{\text {carb }}=$ carbonate carbon; $\mathrm{g} S=$ gram of sample; $\mathrm{HI}=$ hydrogen index; $\mathrm{OI}=$ oxygen index; $\mathrm{T}_{\mathrm{m}}=$ pyrolysis temperature; $\mathrm{I}=$ indigenous $\mathrm{S}_{2}$ peak; $\mathrm{R}_{1}$ and $\mathrm{R}_{2}$ $=$ recycled $S_{2}$ peaks. Blanks indicate not detected. See text for definitions of $S_{1}, S_{2}$, and $S_{3}$. 
APPENDIX B

Kerogen Analyses: Visual Composition and Atomic Ratio Data

\begin{tabular}{|c|c|c|c|c|c|c|}
\hline \multirow[b]{2}{*}{$\begin{array}{l}\text { Hole-Core-Section } \\
\text { (interval in } \mathrm{cm} \text { ) }\end{array}$} & \multirow{2}{*}{$\begin{array}{l}\text { Sub-bottom } \\
\text { depth } \\
\text { (m) }\end{array}$} & \multicolumn{3}{|c|}{ Composition } & \multicolumn{2}{|c|}{ Atomic ratio } \\
\hline & & $\begin{array}{l}\text { AM } \\
(\%)\end{array}$ & $\begin{array}{l}\text { HB } \\
(\%)\end{array}$ & $\begin{array}{l}\text { WC } \\
(\%)\end{array}$ & $\mathrm{H} / \mathrm{C}$ & $\mathrm{N} / \mathrm{C}$ \\
\hline \multicolumn{7}{|l|}{ Site 582} \\
\hline $582-1-4,70-74$ & $0.00-5.22$ & 66 & 11 & 23 & & \\
\hline $582-3-6,44-48$ & $19.40-27.36$ & 75 & 14 & 11 & & \\
\hline $582 \mathrm{~A}-1-3,130-134$ & $29.10-33.42$ & 70 & 17 & 13 & 0.81 & 0.0320 \\
\hline $582 \mathrm{~A}-2-3,22-26$ & $58.20-61.44$ & 80 & 9 & 11 & 1.09 & 0.0404 \\
\hline $582 A-3-3,11-16$ & $67.90-71.04$ & 72 & 14 & 14 & 1.04 & 0.0454 \\
\hline $582 A-5-1,63-68$ & $87.30-87.96$ & 72 & 7 & 21 & 1.12 & 0.0344 \\
\hline $582 \mathrm{~A}-8-2,100-105$ & $116.10-118.63$ & 75 & 11 & 14 & 0.99 & 0.0378 \\
\hline $582 \mathrm{~A}-10-5,82-87$ & $135.50-142.35$ & 74 & 13 & 13 & 1.06 & 0.0356 \\
\hline $582 \mathrm{~A}-12-1,123-128$ & $154.80-156.06$ & 77 & 14 & 9 & 0.86 & 0.0307 \\
\hline $582 A-15-3,62-67$ & $183.60-187.24$ & 72 & 15 & 13 & 0.99 & 0.0324 \\
\hline $582 \mathrm{~A}-18-1,45-50$ & $212.50-212.97$ & 73 & 22 & 5 & 0.94 & 0.0308 \\
\hline $582 \mathrm{~A}-20-1,89-94$ & $231.90-232.82$ & 74 & 12 & 14 & 0.90 & 0.0342 \\
\hline $582 \mathrm{~A}-22-2,61-65$ & $251.10-253.23$ & 83 & 6 & 11 & 0.81 & 0.0327 \\
\hline $582 A-24-1,108-112$ & $270.30-271.40$ & 76 & 12 & 12 & 0.95 & 0.0472 \\
\hline $582 A-26-3,60-65$ & $289.50-293.13$ & 86 & 8 & 6 & 0.89 & 0.0314 \\
\hline $582 \mathrm{~A}-29-1,116-120$ & $318.30-319.48$ & 73 & 13 & 14 & & \\
\hline $582 \mathrm{~A}-31-1,138-143$ & $337.50-338.91$ & 80 & 4 & 16 & 0.79 & 0.0297 \\
\hline $582 A-34-1,68-73$ & $365.90-366.61$ & 77 & 12 & 11 & 0.88 & 0.0351 \\
\hline $582 \mathrm{~A}-36-1,60-65$ & $384.80-385.43$ & 82 & 13 & 5 & 0.85 & 0.0316 \\
\hline $582 A-38-2,75-81$ & $403.80-406.08$ & 81 & 12 & 7 & 0.79 & 0.0292 \\
\hline $582 A-40-2,33-38$ & $422.60-424.46$ & 68 & 24 & 8 & 1.14 & 0.0338 \\
\hline $582 A-42-1,76-78$ & $441.50-442.27$ & 83 & 11 & 6 & 0.97 & 0.0399 \\
\hline $582 \mathrm{~A}-44-1,70-73$ & $460.50-461.22$ & 89 & 5 & 6 & & \\
\hline $582 \mathrm{~A}-48, \mathrm{CC}$ & $498.60-499.76$ & 78 & 11 & 11 & & \\
\hline $582 \mathrm{~A}-50-3,33-35$ & $517.80-521.14$ & 86 & 6 & 8 & 0.84 & 0.0295 \\
\hline $582 A-52-2,28-30$ & $537.00-538.79$ & 83 & 13 & 4 & 0.87 & 0.0285 \\
\hline $582 \mathrm{~A}-54-1,92-94$ & $556.30-557.23$ & 81 & 6 & 13 & & \\
\hline $582 A-55-2,63-66$ & $566.00-568.15$ & 87 & 3 & 10 & & \\
\hline $582 \mathrm{~A}-59-2,60-62$ & $604.50-606.61$ & 86 & 6 & 8 & 1.00 & 0.0327 \\
\hline $582 \mathrm{~A}-61-1,47-49$ & $623.70-624.18$ & 73 & 7 & 20 & 0.86 & 0.0353 \\
\hline $582 \mathrm{~A}-62-2,87-90$ & $633.30-635.68$ & 79 & 11 & 10 & & \\
\hline $582 A-63-1,84-86$ & $642.90-643.75$ & 81 & 12 & 7 & 1.07 & 0.0419 \\
\hline $582 \mathrm{~A}-64-3,92-94$ & $652.50-656.43$ & 87 & 5 & 8 & 1.00 & 0.0404 \\
\hline $582 \mathrm{~A}-65-1,24-26$ & $662.10-662.35$ & 67 & 11 & 22 & 1.25 & 0.0444 \\
\hline $582 \mathrm{~A}-66-3,41-43$ & $671.80-675.22$ & 68 & 16 & 16 & 1.12 & 0.0443 \\
\hline $582 \mathrm{~A}-68-1,146-148$ & $691.20-692.67$ & 74 & 5 & 21 & 0.92 & 0.0431 \\
\hline $582 \mathrm{~A}-70-2,48-51$ & $710.60-712.60$ & 77 & 15 & 8 & & \\
\hline
\end{tabular}

Site 583

$\begin{array}{lcrrrrr}583-1-1,18-21 & 0.00-0.20 & 81 & 10 & 9 & & \\ 583-3-3,91-93 & 15.00-18.92 & 76 & 15 & 9 & & \\ 583-5-3,94-97 & 32.50-36.45 & 78 & 13 & 9 & & \\ 583-7-1,90-93 & 45.90-46.82 & 84 & 6 & 10 & & \\ 583-8-3,120-122 & 55.40-59.61 & 74 & 15 & 11 & & \\ 583-11-1,90-93 & 73.50-74.42 & 82 & 8 & 10 & 0.94 & 0.0362 \\ 583-13-1,83-85 & 87.00-87.84 & 78 & 8 & 14 & 0.89 & 0.0344 \\ 583-17-1,10-13 & 107.00-107.12 & 79 & 14 & 7 & 0.79 & 0.0288 \\ 583-19-1,60-63 & 117.00-117.62 & 79 & 13 & 8 & 0.94 & 0.0323 \\ 583 \mathrm{D}-10-1,45-48 & 133.20-133.67 & 85 & 11 & 4 & 1.03 & 0.0399 \\ 583 \mathrm{D}-13-1,90-95 & 162.30-163.22 & 72 & 16 & 12 & 1.19 & 0.0375 \\ 583 \mathrm{D}-15-1,40-45 & 181.70-182.13 & 77 & 8 & 15 & & \\ 583 \mathrm{D}-17-1,40-45 & 201.00-201.43 & 86 & 7 & 7 & & \\ 583 \mathrm{D}-19-1,124-128 & 220.20-221.46 & 83 & 8 & 9 & & \\ 583 \mathrm{D}-22-2,23-28 & 249.30-251.06 & 80 & 9 & 11 & 1.20 & 0.0362 \\ 583 \mathrm{~F}-14-2,46-49 & 275.70-277.68 & 80 & 10 & 10 & 1.10 & 0.0296 \\ 583 \mathrm{~F}-16-1,42-45 & 295.00-295.43 & 77 & 10 & 13 & & \\ 583 \mathrm{~F}-18-3,40-43 & 314.20-317.62 & 78 & 13 & 9 & & \\ 583 \mathrm{~F}-20-2,69-74 & 333.60-335.82 & 85 & 8 & 7 & & \\ 583 \mathrm{~F}-22-1,116-120 & 352.90-354.08 & 87 & 5 & 8 & & \\ 583 \mathrm{~F}-25-1,132-134 & 381.80-383.13 & 90 & 6 & 4 & & \\ 583 \mathrm{~F}-26-2,43-46 & 391.50-393.45 & 76 & 16 & 8 & & \\ 583 \mathrm{~F}-27-2,50-51 & 401.20-403.21 & 83 & 10 & 7 & & \\ 583 \mathrm{~F}-29-2,24-27 & 420.40-422.16 & 88 & 9 & 3 & & \\ 583 \mathrm{G}-15-1,138-140 & 442.00-443.39 & 80 & 13 & 7 & & \end{array}$

Site 584

$584-1-3,118-123$ $584-3-2,89-94$ 584-5-3, $113-118$ $584-7-1,113-118$

584-10-1, 113-118

$584-11-4,69-71$

$584-13-4,83-85$

$584-14-1,42-47$
$0.00-4.21$

20.00-22.42

$38.80-42.96$

$57.80-58.96$

$86.50-87.66$

$96.00-101.20$

$115.10-120.44$

$124.70-125.15$

\begin{tabular}{rrrrr}
92 & 4 & 4 & & \\
92 & 5 & 3 & & \\
83 & 13 & 4 & 1.25 & 0.0587 \\
89 & 8 & 3 & 1.31 & 0.0602 \\
89 & 6 & 5 & 1.20 & 0.0586 \\
84 & 10 & 6 & 1.20 & 0.0564 \\
92 & 4 & 4 & & \\
87 & 6 & 7 & 1.21 & 0.0581 \\
\hline
\end{tabular}

Appendix B. (Continued).

\begin{tabular}{|c|c|c|c|c|c|c|}
\hline \multirow[b]{2}{*}{$\begin{array}{l}\text { Hole-Core-Section } \\
\text { (interval in } \mathrm{cm} \text { ) }\end{array}$} & \multirow{2}{*}{$\begin{array}{l}\text { Sub-bottom } \\
\text { depth } \\
\text { (m) }\end{array}$} & \multicolumn{3}{|c|}{ Composition } & \multicolumn{2}{|c|}{ Atomic ratio } \\
\hline & & $\begin{array}{l}\text { AM } \\
(\%)\end{array}$ & $\begin{array}{l}\mathrm{HB} \\
(\%)\end{array}$ & $\begin{array}{l}\text { WC } \\
(\%)\end{array}$ & $\mathrm{H} / \mathrm{C}$ & $\mathrm{N} / \mathrm{C}$ \\
\hline
\end{tabular}

Site 584 (Cont.)

584-17-1, 113-118 $153.70-154.86$

584-19-1, 113-118 $173.10-174.26$

584-21-1, 113-118 $192.50-193.66$

584-23-1, 113-118 211.70-212.86

584-24-4, 78-83 221.30-226.60

584-26-1, 74-76 240.30-241.05

584-28-1, 111-114 259.30-260.43

584-30-1, 90-93 278.30-279.22

584-32-1, 79-81 297.30-298.10

584-34-2, 75-78 316.40-318.67

584-36-1, 4-7 335.60-335.66

584-38-1, 92-94 354.60-355.53

584-39-3, 92-94 364.10-368.03

$584-42-4,80-82 \quad 392.90-398.21$

584-44-4, 99-101 $\quad 412.30-417.80$

584-46-1, 62-66 431.50-432.15

$584-48-2,110-112 \quad 450.50-453.11$

$584-49-2,125-128 \quad 460.10-462.87$

$584-51-1,123-126 \quad 479.30-480.55$

584-53-1, 86-89 498.50-499.38

584-54-4, 99-101 508.10-513.60

584-56-1, 69-71 527.10-527.80

584-58-1, 125-127 546.10-547.36

$584-60-2,12-15 \quad 565.10-566.74$

584-62-1, 44-47 $\quad 584.10-584.56$

584-64-1, 51-53 603.20-603.72

$584-66-1,7-9 \quad 622.40-622.48$

$584-68-1,109-112 \quad 641.80-642.90$

$584-70-1,38-40 \quad 661.20-661.59$

584-72-1, 75-77 $\quad 680.60-681.36$

584-74-1, 118-121 $\quad 699.80-700.99$

584-76-3, 40-45 719.10-722.53

$584-78-1,32-34 \quad 738.50-738.83$

$584-80-4,12-15 \quad 757.50-762.14$

584-81-1, 63-65 $\quad 767.00-767.64$

584-83-2, 144-146 $786.40-789.35$

$584-85-1,60-61 \quad 805.80-806.40$

$584-87-1,133-134 \quad 825.20-826.54$

$584-89-2,53-58 \quad 844.40-846.46$

584-91-1, 40-44 863.70-864.12

$584-93-2,7-10 \quad 883.10-884.69$

584-95-1, 93-96

584-96-1, 147-149

$902.50-903.45$

911.20-912.68

\begin{tabular}{|c|c|c|c|c|}
\hline 91 & 6 & 3 & & \\
\hline 89 & 7 & 4 & & \\
\hline 94 & 4 & 2 & 1.27 & 0.0654 \\
\hline 94 & 5 & 1 & & \\
\hline 90 & 6 & 4 & 1.19 & 0.0549 \\
\hline 85 & 12 & 3 & 1.20 & 0.0585 \\
\hline 92 & 4 & 4 & & \\
\hline 91 & 4 & 5 & & \\
\hline 94 & 2 & 4 & & \\
\hline 90 & 3 & 7 & & \\
\hline 91 & 6 & 3 & & \\
\hline 95 & 3 & 2 & & \\
\hline 93 & 3 & 4 & 1.16 & 0.0548 \\
\hline 90 & 2 & 8 & & \\
\hline 75 & 2 & 20 & 1.11 & 0.0485 \\
\hline 89 & 5 & 6 & & \\
\hline 85 & 7 & 8 & & \\
\hline 78 & 12 & 10 & & \\
\hline 77 & 7 & 16 & & \\
\hline 78 & 11 & 11 & & \\
\hline 87 & 7 & 6 & & \\
\hline 79 & 5 & 16 & 1.19 & 0.0485 \\
\hline 81 & 6 & 13 & & \\
\hline 83 & 9 & 8 & 1.21 & 0.0524 \\
\hline 77 & 15 & 8 & 1.25 & 0.0380 \\
\hline 83 & 12 & 5 & 1.28 & 0.0473 \\
\hline 80 & 11 & 9 & 1.20 & 0.0484 \\
\hline 86 & 9 & 5 & 1.36 & 0.0379 \\
\hline 68 & 26 & 6 & & \\
\hline 95 & 3 & 2 & & \\
\hline 96 & 2 & 2 & 1.00 & 0.0395 \\
\hline 85 & 7 & 8 & & \\
\hline 90 & 7 & 3 & 1.10 & 0.0467 \\
\hline 89 & 7 & 4 & & \\
\hline 90 & 7 & 3 & & \\
\hline 86 & 7 & 7 & & \\
\hline 88 & 9 & 3 & 1.15 & 0.0533 \\
\hline 85 & 10 & 5 & & \\
\hline 94 & 2 & 4 & & \\
\hline 88 & 2 & 10 & 1.17 & 0.0462 \\
\hline 86 & 2 & 12 & & \\
\hline 92 & 4 & 4 & & \\
\hline 84 & 6 & 10 & 1.15 & 0.0514 \\
\hline 83 & 9 & 8 & & \\
\hline
\end{tabular}

Note: $\mathrm{AM}=$ amorphous; $\mathrm{HB}=$ herbaceous; $\mathrm{WC}=$ woody-coaly; blanks indicate not analyzed. 
APPENDIX C

Reflectance Data of Vitrinite-Huminite and Inertinite

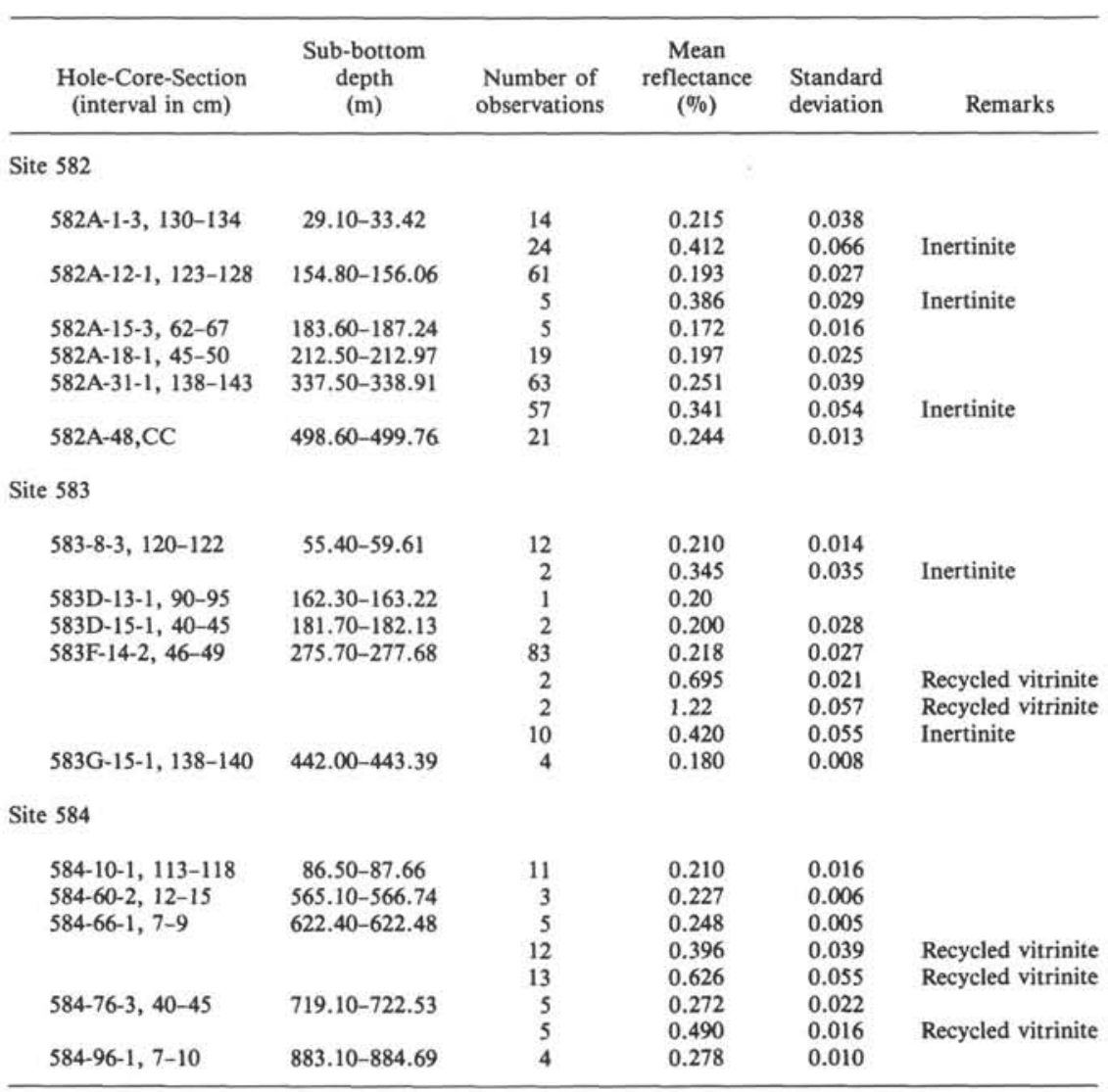

